\title{
Výchovná a vzdělávací role sportu u myslitelů Sókrata, Platóna a Aristotela ve vztahu k problematice dobrého sportu a vedení dobrého života
}

\author{
Lukáš Mareš \\ Teologická fakulta \\ Jihočeská univerzita v Českých Budějovicích \\ Branišovská 1645, 37005 České Budějovice \\ mares103@tf.jcu.cz
}

Př́spěvek se věnuje problematice antického řeckého sportu, konkrétně významu sportovních zápolení a jejich výchovné a vzdělávací roli. Pozornost autor věnuje rozboru pozic filosofü Sókrata, Platóna a Aristotela. Po nastínění kontextu tématu představuje a interpretuje základní filosofické a náboženské premisy sportovního výkonu a jeho výchovné role. Ǩadí mezi ně úsilí o dosažení božské přízně, nesmrtelnosti, vyššího společenského postavení, ale i ideálů kalokagathia, areté a dalších ctností. Důležitý rozměr antického sportu spatřuje rovněž v jeho formativním potenciálu směřujícím $\mathrm{k}$ přípravě na duševní život. Hlavní část př́spěvku se věnuje přístupu k pohybovým zápolením u filosofư Sókrata, Platóna a Aristotela, kteř́ svými úvahami k chápání výchovné role sportu podstatně přispěli. Následně se autor zaměřuje na identifikaci dobrého sportu podle zmíněných myslitelů a na zkoumání role sportu v kontextu dobrého života, který nahlíží v aristotelském rámci jako dosahování blaženosti (eudaimonia). Cílem textu je identifikovat a vyzdvihnout výchovný smysl sportování, poukázat na jeho filosofické konotace a možnou roli sportu v otázce vedení dobrého života.

Klíčová slova: filosofie sportu, filosofie výchovy, areté, kalokagathia, dobrý sport, dobrý život 


\section{Nástin kontextu tématu: antické Řecko a sport}

Antický řecký sport ${ }^{1}$ představuje komplexní systém pohybových, herních a soutěživých aktivit, které jsou s ohledem na místo i historickou epochu prodchnuty hodnotami, filosofickými i náboženskými koncepcemi a ideály tehdejších Řeků. Řecká kultura se vyznačovala značnou soutěživostí, která tvoří důležitý aspekt právě sportovního zápolení. Dle Huizingy: „گ̌Rekové měli ve zvyku soutěžit ve všem, v čem bylo možné se utkat.“2 Závodění a soutěžení v nejrůznějších oblastech vystihuje pojem agón, který znamená právě zápas, závod či soutěž. ${ }^{3}$ Sport jakožto herně pohybově zápolivá aktivita tak tvořil základní složku antické řecké kultury a byl neodmyslitelnou součástí života společnosti. ${ }^{4} \mathrm{Ti}$, kteří se odmítali cvičit, byli označováni termínem idiótai jakožto necvičení, duševně či tělesně nezpůsobilí občané, kteří se neúčastnili veřejného života obce. ${ }^{5}$

Při pohledu na původní pohybově zápolivé aktivity si můžeme všimnout několika vzájemně se prolínajících rozměrů. Patří sem rozměr rituálně-náboženský, herní, militantní a výchovně-vzdělávací.

Sportovní zápolení s rituálně náboženským kontextem je typické pro řecké slavnosti. Mezi nejznámější se řadí panhelénské hry (olympijské, pýthijské, isthmické, nemejské) a panathénajské slavnosti. Základním rysem těchto událostí je oslava božstev skrze atletický výkon. ${ }^{6}$ Rozměr herní můžeme chápat v rovině osobního nastavení k činnosti (tzv. herní postoj) a inherentních herních vlastností samotné sportovní aktivity, především však na ontologické rovině jakožto manifestaci základních

1 Užití pojmu sport je s ohledem na jazykový původ i moderní používání tohoto pojmu problematické. Ačkoli sportovní aktivity antických Řeků měly silně rituální, náboženský a filosofický podtext, jsem přesvědčen, že s ohledem na vnitřní aspekty těchto aktivit si můžeme dovolit je označit za sportovní. Je nicméně potřeba zmínit, že dané aktivity s ohledem na jejich provázanost s řeckou kulturou znamenaly v mnoha aspektech něco jiného, než co si pod pojmem sport představujeme dnes. Typickými př́íklady provozovaných sportů jsou běžecké disciplíny, box, zápas, všeboj - pankration, pětiboj - pentathlon, ale i míčové sporty. Pro podrobnější vysvětlení pojmu sport v kontextu antického Řecka vizte např. Kyle (1983, s. 7).

2 Huizinga (1971, s. 72).

3 Bahník et al. (1974, s. 18).

4 Kretchmar et al. (2017, s. 75), Kouřil (2016b, s. 7-28).

5 Kouřil (2016b, s. 9).

6 Do tohoto rozměru lze rovněž zařadit pietní atletické závody popsané Homérem v Íliadě, které uspořádal Achilles na počest zemřelého Patrokla. 
herních struktur kosmu.7 Oporou je zde řecký filosof Hérakleitos, který ve zlomku B52 z Hippolyta píše: „Věk je hrající si chlapec, sunoucí kaménky ve hře - chlapecké království. ${ }^{8}$ Jirásek uvádí, že Hérakleitova slova o hře mají zdůraznit dialektičnost pohledu na kosmos, tedy především změnu, proměnlivost, variabilitu, novost. Podstatnými znaky této dialektické hry a soutěžení na ontologické rovině jsou zápas a boj. ${ }^{9}$ Třetí rozměr sportu je právě militantní, kdy slouží jako příprava k boji. Typickým představitelem tohoto rozměru je Sparta se svou vojensky orientovanou výchovou (agógé). Tělesně zápolivá cvičení jakožto příprava budoucích vojáků jsou ovšem typická i pro athénská gymnasia. V nich se můžeme setkat se čtvrtým rozměrem sportu, kterým je komplexní výchova řecké mládeže i dalších občanů polis. Tento rozměr sportovních aktivit je úzce provázán s filosofickými koncepcemi vedení dobrého života a představuje důležitou součást komplexního rozvoje řeckého člověka. V příspěvku mu věnuji největší pozornost.

Problematice výchovné role sportu v antice se jižřada studií věnovala. ${ }^{10}$ Inovativní prvek tohoto příspěvku spatřuji v podrobnějším rozpracování otázky dobrého sportu (zejména jeho různých rovin) s ohledem na jeho výchovný potenciál a v nástinu jeho role ve vedení dobrého života. Základní výzkumné otázky, které $\mathrm{v}$ příspěvku rozpracovávám, jsou: Jaký sport můžeme označit za dobrý a proč? Jakou roli sport může mít v otázce vedení dobrého života? Jednotlivé kapitoly jsou strukturovány tak, aby článek na tyto otázky nabídl ucelenou odpověd'.

Text je ryze teoretickou studií pohybující se na pomezí oborů filosofie a historie. Při psaní využívám reprezentativní odbornou literaturu k tématu. Čerpám především z českých a anglických odborných článků a monografiíadočeštinypřeložených původních řeckýchpramenů.Citace z anglických zdrojů jsou mými vlastními překlady. V textu použité řecké termíny uvádím kurzívou v české transkripci, která vychází z Prachova

7 Při aplikaci herních kosmických struktur do konkrétnější skutečnosti, jakou je sport, je potřeba upozornit na skrytou premisu, totiž že sport je ve své podstatě herní aktivitou. Tato teze není odbornou komunitou filosofư sportu automaticky přijímána, nicméně existuje řada autorů (včetně mě), kteří se k ní v různých ohledech kloní (např. Suits, Meier, Connor ad.). Co znamená herní, ovšem vyžaduje důkladnějšího zkoumání, pro které není v tomto textu prostor.

8 Svoboda (1962, s. 62).

9 Jirásek (2001, s. 87), Svoboda (1962, s. 54, 57-58).

10 Za pozornost stojí např́íklad práce H. L. Reidové, I. Jiráska či A. Hogenové. 
Řecko-českého slovníku. ${ }^{11}$ Význam původních řeckých termínů odpovídá zmíněnému slovníku, př́padně je uvedeno jinak. Jména zahraničních autorek jsou $\mathrm{v}$ textu přechylována, zatímco $\mathrm{v}$ odkazu na jejich díla nikoli. Důraz kladu na odkrývání a analyzování filosofického rozměru řešeného tématu. Při psaní používám konkrétně tyto metody: deskripce, komparace, kritická analýza, interpretace a syntéza dílčích informací. Historické období, na které se zaměřuji primárně, představuje antické Řecko v rozmezí mezi 5. až 4. stoletím př. n. l. (klasické období).

\section{Základní premisy sportovního výkonu s ohledem na jeho výchovnou roli}

Charakteristickým rysem sportovních zápolení i celkového způsobu života antických Řeků je na jedné straně touha vyniknout ve společenské hierarchii (sociální rozměr), na druhé straně snaha zajistit si př́zeň bohů a dosáhnout nesmrtelnosti (individuální rozměr). Vyniknutím mohl získat atlet uznání a proměnit tak své společenské postavení. Zejména jakožto olympijský vítěz byl rovněž vzorem pro mládež, čímž sehrával i edukační roli. Dle Kouřila antická řecká společnost pod vlivem mytologie a herojů uznávala skvělé bojovníky i atlety, kterým se podařilo zvítězit na sportovně náboženských slavnostech. ${ }^{12}$ Osobní vyniknutí zajištovalo řeckému občanovi zanechání nesmazatelné stopy a přiblížení se na roveň bohů. Ke snaze po získání nesmrtelnosti uvádí Arendtová toto: „Touha Řeků dosáhnout nesmrtelnosti vyrůstala z vědomí, že jsou jakožto smrtelníci obklopeni nepomíjející přírodou a že jejich život se odehrává před zrakem bohů neznajících smrt. ${ }^{{ }_{13}}$ Snahou bylo skrze nesmrtelné činy zanechat ve světě nepomíjivé stopy a prokázat, že také člověk má božskou přirozenost.

V kontextu výchovné/formativní role sportu je potřeba upozornit na jeho selektivní, avšak i rovnoprávný rozměr. Sportování antických Řeků se pojí s dobrovolností vynaloženého úsilí, která je kontrastní vůči fyzickým aktivitám otroků, kteří na výběr neměli. ${ }^{14}$ Svobodný občan

\footnotetext{
11 Prach (2005).

12 Kouřil (2016a, s. 15), Kouřil (2019, s. 79).

13 Arendt (2009, s. 29-30).

14 Reid (2012a, s. 286).
} 
řeckého původu se mohl účastnit sportovních zápolení a byl si v nich roven ostatním občanům. Oproti tomu byli z aktivní účasti na sportování vyloučeni otroci, barbaři, vrazi a v řadě př́padů i ženy. ${ }^{15}$ Olivová upřesňuje, že barbaři a otroci, stejně tak i neprovdané dívky se mohli účastnit všeřeckých slavností jako diváci. Naproti tomu provdané ženy měly i pasivní účast zakázanou. ${ }^{16}$ Rovnost a vzájemné spojení, jež byly typickými znaky řecké demokracie 5 . století př. n. l., byly často vyjádřeny nahotou sportovců. Kouřil situuje rovnoprávnost (isonomia) zejména do prostředí gymnasií, $k$ dy si ve vzájemném střetu byli atleti sociálně rovni (isos). ${ }^{17}$ Sport nebyl (jako v 8. a 7. století př. n. l.) výsadou aristokracie, ${ }^{18}$ ale byl záležitostí svobodných Řeků.

Důležitou metou nejen dobrovolného sportovního úsilí a námahy (ponos), ale i dalších činností antických Řeků, bylo dosahování a manifestace areté. Patočka daný pojem výstižně charakterizuje jako výtečnost či lépe řečeno pravost ve smyslu být tím, čím vskutku daná věc jest. ${ }^{19} \mathrm{~S}$ odkazy na filosofy Sókrata a Platóna si všímá filosofického rozměru areté, který odkazuje $\mathrm{k}$ hlubokému kontaktu jedince $\mathrm{s}$ celkem reality: „Areté není privátně individuální ctnost; je to něco pevně určeného, co se přesto děje v měnivých konkrétních situacích; je to úsilí člověka o prohlédnutí celku v zasazení do konkrétní situace. ${ }^{\text {" }}{ }^{20}$ Jirásek s odkazem na Hogenovou upozorňuje na problematičnost vymezení daného pojmu a rovněž na proměnlivost jeho obsahu s ohledem na historický kontext. Podle historického vývoje a proměn společenských preferencí tak do něj patř́i statečnost v boji, výkonnost, ale i velkorysost, ušlechtilost, vzdělanost či duchovní velikost. ${ }^{21}$ Sportování hrálo důležitou roli ve snaze dosahovat a demonstrovat právě areté.

Jako důležité $\mathrm{s}$ ohledem na výchovnou roli sportu se rovněž jeví filosoficko-antropologické poznatky tehdejších řeků. Helénská tradice

15 Výjimku tvoří Sparta, slavnosti na počest bohyně Héry (tzv. héraje) či Platónova Akademie, kde údajně ženy byly.

16 Olivová (1988, s. 117).

17 Kouřil (2019, s. 76).

18 Olivová (1988, s. 95-96).

19 Patočka (1999, s. 58, 75).

20 Patočka (1996, s. 33).

21 Jirásek (2005, s. 213-214). 
vycházela $\mathrm{z}$ předpokladu, že lidský pohyb (kinésis) začíná $\mathrm{v}$ duši $\left(p s y c h e^{22}\right)$, která je hybnou silou těla (sóma). ${ }^{23}$ Atletovo tělo jakožto produkt dobrovolného a intencionálního pohybu je pak vyjádřením kvality atletovy psyché. ${ }^{24}$ Patočka v odkazu na Platóna označuje duši jako to, co se samo uvádí v pohyb (to auto heauto kinoun) a zahrnuje pluralitu pohybů, mezi kterými je napětí. Proto Patočka ř́iká, že duše je celou svou povahou časová pohyblivost, která se navíc v platónském pojetí uvádí v pohyb tím, že žije ve vztahu k dobru (agathon). ${ }^{25}$ Tělesná krása odráží krásu duševní, přičemž takto kultivovaná duše se podobá duši božské, pojí se s koncepty dobra a pravdy a manifestuje se v kráse tělesné. ${ }^{26}$ Kultivovaná duše a kultivované tělo jsou základními cíli tehdejší filosofie výchovy. Důraz pouze na jednu ze složek by znamenal disharmonii a v posledku úpadek jedince-atleta jakožto člověka. Sportovní zápolení jakožto tělesný projev je tak v posledku zároveň duševní záležitostí, nebot' nejde pouze o předvedení pohybové dovednosti, tělesné síly či obratnosti, ale i o předvedení duševní stránky jedince (jeho areté např. ve smyslu odvahy, zarputilosti, odolnosti) manifestované v tělesném projevu. Jde o to předvést v plnosti komplexní pohybový rozvrh lidské bytosti, který zahrnuje ji celou, jako jednotu těla a duše. Atletický výkon ve vrcholném období řeckého rozkvětu zahrnoval tuto dimenzi. Vystihuje ji pojem kalokagathia, který značí „tělesnou krásu spojenou s duševní ušlechtilostí v harmonické jednotě“. ${ }^{27}$

Důležitou roli ve výchově a formování řeckých občanů sehrála gymnasia. $V$ těchto institucích se sportovní zápolení ${ }^{28}$ významně provazuje s filosofií. Dokladem je nejen př́tomnost filosofů a rozpravy s cvičícími mladíky, ale i hlubší ukotvení významu tělesného pohybu a cvičení pro

$22 \mathrm{~V}$ řeckém pojetí duše zahrnuje prvky jako racionální kalkulace, emoční projevy i fyzické žádosti.

23 Reid (2011, s. 5).

24 Reid (2009, s. 45).

25 Patočka (1999, s. 52-53, 76).

26 Reid (2012a, s. 281-297). Dle Zowislové (2009, s. 90) se myšlenka, že tělesná krása je odrazem ctností lidské bytosti, objevuje již v Homérově Íliadě.

27 Bahník et al. (1974, s. 306). Podrobně o pojmu kalokagathia a jeho různých významech pojednává Martínková (2012).

28 Všimněme si, že užitý pojem „sportovní zápolení“ v tomto kontextu odkazuje především k tělesným cvičením využívajícím konkrétní sportovní aktivity či prvky. Sport ve smyslu soutěžní aktivity se objevuje zejména na řeckých slavnostech. 
rozvoj člověka a správné vedení života. Jirásek hovoří o gymnasiích jako o místech, v nichž se spojovala všestranná péče o tělo s všestrannou péčí o duši. V průběhu 7. a 6. století př. n. l. se dle něho rodí zjemnělý ideál areté, harmonicky vyvažující lidskou osobnost, a ideál kalokagathia, propojující duchovní prvky kultury s kulturou fyzickou. Zmíněné ideály se realizovaly prostřednictvím praktické výchovy (paideia), v níž šlo o zdokonalování lidského těla prostřednictvím tělesných cvičení, ale také o rozvoj lidského vědomí skrze filosofické rozhovory: „Tak bylo obsahem starořecké paideie vychování fyzické a filosofické, potvrzením humanistického ideálu, v němž areté lidského činu je aktivitou těla a skutečností myšlení." Základní obsahovou strukturou této výchovy bylo umění músické a gymnastické, kterými se člověk rozvíjel nikoli jednostranně, nýbrž komplexně. ${ }^{29}$ Předmětem diskusí je erotický poměr mezi mladíky a staršími občany navštěvujícími gymnasia. Jirásek s ohledem na nahotu a pederastii uvádí, že se nejednalo primárně o sexuální orientaci, ale spíše o specifické sociální vztahy iniciačních rituálo̊, konkrétně vztahy muže k vybranému chlapci jako součást přechodu z dětství do dospělosti. ${ }^{30}$

Podrobnější rozpracování edukačního rozměru sportu poskytuje následující kapitola věnovaná pohledu tří řeckých filosofư na sportovní výkon.

\section{Postoj filosofů k výchovné roli sportu: Sókratés, Platón, Aristotelés}

Z dochovaných zdrojů je patrné, že antičtí řečtí filosofové věnovali pohybovým aktivitám pozornost. V zásadě můžeme rozlišit mezi jejich samotnou participací ve sportovních zápoleních, pasivní účastí na závodech a teoretickým rozborem i kritickou analýzou sportovních aktivit, zejména ve vztahu k filosofii výchovy a otázce vedení dobrého života. ${ }^{31}$ Cílem následujících částí je podrobné představení náhledu

29 Jirásek (2005, s. 215-218). Kouřil (2019, s. 75) nastiňuje, že sport byl provázán s timé (ctí, vážností) a dalšími ctnostmi prostupujícími řeckou společností.

30 Jirásek (2009, s. 13).

31 O aktivní i pasivní účasti filosofů na sportovních událostech pojednává např. Jirásek (2005, s. 274). 
na sport a jeho roli ve výchovném a vzdělávacím procesu u filosofů Sókrata, Platóna a Aristotela. Představuji rovněž obecnější východiska jejich uvažování, zejména s ohledem na vedení dobrého života. Nejde mi o rekonstrukci jejich celkové argumentace, ale o prezentaci hlavních pohledů na roli sportu ve výchovném procesu. Výběr těchto autorů odůvodňuji jejich zásadním vlivem na pozdější vývoj filosofického myšlení nejen v oblasti filosofie sportu a rovněž jejich podrobným rozpracováním filosoficko-antropologických úvah o člověku, které jsou pro uvažování o sportu a jeho významu důležitou podmínkou. ${ }^{32}$ Kromě uvedených myslitelů můžeme v souvislosti s výchovou a sportem zmínit např. Pýthágoru, který údajně lákal mladé atlety ke studiu filosofie. ${ }^{33}$

\subsection{Sókratés - sportováním k rozvoji rozumu a ctnosti}

Zmínky o filosofu Sókratovi máme od jeho současníků a pozdějších myslitelů - Platóna, Aristotela, Aristofana, Xenofónta či Diogena Laertia. Badatelé současnosti i nedávné historie postoj Sókrata ke sportu a pohybovým aktivitám popisují, interpretují a kriticky hodnotí. Obecně můžeme říci, že Sókratův postoj ke sportu je podmíněný jeho uvažováním o důležitosti kultivace těla pro rozumovou aktivitu a také závislý na tom, v jaké intenzitě se sportovní činnosti daný jedinec věnuje. Dle Olivové byl Sókratés proti přepínání atletického tréninku a do popředí kladl diskuse o filosofických otázkách. ${ }^{34} \mathrm{Na}$ druhou stranu Guttmann uvádí, že obdivoval tělesnou dokonalost a ačkoli sám primárně filosof, opovrhoval těmi, kteří se nezajímali o své tělo. ${ }^{35}$ Tyto pozice se objevují v Xenofóntových Vzpomínkách na Sókrata a Platónovu dialogu Ústava, které považuji za vhodné zdroje pro demonstraci Sókratova postoje ke sportování a výchově obecně, nebot' Xenofón i Platón se oběma oblastem věnují.

V jedné z pasáží prvně zmíněného díla ${ }^{36}$ dokazuje Sókratés svému př́teli Epigenovi, že dobrý tělesný stav je po všech stránkách výhodnější

32 Zowislo (2009, s. 91).

33 Podrobněji Reid (2011, s. 44), Reid (2012b, s. 10, 145-146).

34 Olivová (1988, s. 136). Autorka mj. uvádí, že Sókratés pěstoval gymnastiku a tanec do vysokého stáří.

35 Guttmann (2004, s. 23).

36 Xenofón (1972, kniha III, část 12). 
než tělesná zchátralost. Vyzdvihuje zde význam vojenských tělesných cvičení jak pro tělo, tak pro duši:

„... v žádném jiném zápase ani $\mathrm{v}$ žádné činnosti na tom neproděláš, vycvičíšlli lépe své tělo... I tam, kde se zdá, že upotřebení těla je nepatrné, totiž při myšlení, i tam, jak každý ví, mnozí dělají velké chyby právě proto, že jejich tělo není zdravé.“

Sókratés zde upozorňuje na negativní dopady špatného tělesného stavu a na důležitost starat se o svou tělesnou složku skrze pohyb. Lze se domnívat, že zde má na mysli sportovní aktivity spíše než pohyb při práci, neboť Řekové spíše dávali přednost svobodnému vyjádření pohybu před nucenými aktivitami, které vnímali jako podřadné. Vyzdvižením významu tělesného pohybu pro myšlenkovou aktivitu prezentuje Sókratés tělesné cvičení jako podmínku a prostř̌edek duševního rozvoje. Zároveň oceňuje estetický rozměr cvičení, které může člověku přidat na kráse vzhledu a oddálit stář́.

Pro uvažování o výchovné roli sportu je podstatné zmínit Sókratův důraz na uměřené tělesné cvičení. V Platónově dialogu Ústava Glaukón na základě Sókratova vedení nastiňuje negativa extrémů výchovy: „Ti, kteří se věnují výlučně tělesnému vzdělání, se tím stávají mnohem surovější, než je třeba, a ti, kdo múzickému umění, stávají se zjemnělými daleko víc, než aby je to mohlo zdobit.“" ${ }^{37}$ Jako správnou chápe Sókratés v Ústavě střední cestu mezi dvěma extrémy:

„Toho, kdo nejlepším způsobem směšuje s múzickými uměními gymnastické vzdělávání a podává je duši v nejpřesnější míře, bychom správně označili jako člověka na nejvyšší míru múzicky dokonale vzdělaného a nejharmoničtějšího..." ${ }^{38}$

V Xenofóntových Vzpomínkách Sókratés dále vyzdvihuje důležitost ustavičné tvrdé práce pro získání kvalitních dovedností a osobní kultivo-

37 Platón (1993, 410d).

38 Tamtéž, 412a. 
vanosti. Důležitou pomoc přitom poskytují autority a odborníci, kterým je dle Sókrata nutno naslouchat, aby se člověk potřebné dovednosti naučil. ${ }^{39}$

S ohledem na celkový obrázek Sókrata, jak je nám dostupný z dochovaných pramenů, můžeme konstatovat, že vedení dobrého života se u tohoto myslitele pojí primárně s rozumovým kritickým uchopováním skutečnosti, které konkrétně znamená snahu poznávat sebe sama, nalézat pravdu o realitě (tedy získávat vědění) a na rovině morálky žít podle ctnosti. Sport v tomto způsobu života plní nejen roli prostředku a podmínky pro kvalitní duševní život, ale je i vyjádřením určitých kvalit naší duše, které se ve sportovním výkonu ukazují a kultivují. Plní tak důležitou, avšak nikoli tu nejpodstatnější podmínku pro vedení dobrého života.

\subsection{Platón - sport jako příprava na duševní život}

Filosof Platón si uvědomoval důležitost tělesného pohybu a sportu ve výchovném procesu. Aktivně se věnoval zápasení a sportovními kláními se zabýval i ve svých spisech..$^{40}$ Považoval je za důležitý prvek ve výchově řádného občana obce, přičemž vzorem mu byla spartská koncepce. ${ }^{41}$ Tělesný rozvoj měl ovšem, na rozdíl od spartského modelu, jít ruku v ruce s kultivací a harmonizací jednotlivých složek duše, k čemuž sloužilo na jedné straně provozování gymnastických cvičení (gymnastiké), na straně druhé pěstování múzického umění (mousiké). Múzická výchova zbavuje ducha hrubosti, gymnická pak změkčilosti těla. Atletický trénink má u Platóna především utilitární charakter jakožto příprava k válce, komplexní výchova má ovšem vést člověka $\mathrm{k}$ naplněnému životu a rovněž ho připravit na filosofický život. ${ }^{42}$ Základním cílem výchovy a vzdělání je u Platóna, podobně jako u Sókrata, pěstování moudrosti, harmonizace jednotlivých složek duše a usilování o pravdu a dobro. Tyto cíle Reidová označuje za dosažitelné pro ty, kteří mají duše atletů a milují správné věci. ${ }^{43}$

39 Xenofón (1972, kniha IV, část 2).

40 Platónova aktivní účast ve sportu je předmětem diskusí. Dle Guttmanna (2004, s. 23) se Platón v mládí věnoval zápasení a získal ocenění na pýthijských, nemejských a isthmických hrách.

41 Olivová (1988, s. 136).

42 Platón (1993, 412a), Olivová (1988, s. 136), Reid (2007, s. 167-168).

43 Reid (2011, s. 66). Myšlenka, že ideální občané mají mít duši atletů, se objevuje v Platónovu dialogu Zákony (1997, 830a). 
O tom, jak má výchova a vzdělání ideálně vypadat, je pojednáno v dialogu Zákony. Platón zde zdůrazňuje, že výchova a vzdělání mají být dostupné pro obě pohlaví a pro různé věkové kategorie. ${ }^{44}$ Dle athénského hosta je správná výchova ta, jež směřuje ,... k dobrosti již od dětského věku, která vštěpuje dítěti žádost a touhu, aby se stalo dokonalým občanem, umějícím vládnout i dát se ovládat podle spravedlnosti““.45 Naopak přístup, dle něhož je nejdůležitější získání bohatství, tělesné síly či jiné dovednosti postrádající rozumnost, nemá být vủbec nazýván výchovou, protože je nedůstojný a celkově nevhodný. ${ }^{46}$ Vzdělávání a výchova by neměly probíhat násilnou formou, nýbrž co nejpřirozenější cestou, kterou je cesta hraní. To zdůrazňuje Sókratés svému př́teli Glaukónovi v dialogu Ústava: „Tedy, př́teli, nezacházej s dětmi při učení násilně, nýbrž at' se učí hravě, abys také lépe mohl pozorovati, k čemu se kdo svou přirozeností hodí. “47 Hra tak u Platóna vystupuje jako vhodný prostředek k formování dítěte po tělesné i duševní stránce. Pokud je provozována správně, vede ho navíc k získání smyslu pro mravní řád a k poslušnosti vưči zákonům. ${ }^{8}$ Lidská bytost je Platónem navíc pojímána jako přirozeně hravá boží hračka:
„,... proto má každý muž a každá žena ve shodě s touto úlohou hrát co nejkrásnější hry a tak prožít celý svůj život... člověk má prožívat život tak, že hraje jisté hry, obětuje a zpívá a tančí, čímž je schopen zjednávat si milost bohů, nepřátelům pak se bránit a v boji nad nimi vítězit.“49

Platónovo vyzdvižení tělesných zápolení a hry je potřeba vnímat v širším kontextu jeho uvažování. Lze říci, žev posledku jde Platónovi o něcojiného než pouze o tělesnou kultivaci a hraní si. Souhlasím s Dombrowskim, že

\footnotetext{
44 Platón (1997, 805cd, 833cd).

45 Tamtéž, 643e.

46 Tamtéž, 644a.

47 Platón (1993, 536e-537a).

48 Tamtéž, 424e-425a. Jirásek (2001, s. 87) v této souvislosti kritizuje Platónovo doporučení hrát stále stejné hry, což dle Platóna má vést k zachování vážnosti zákonů. Naopak nepř́mo apeluje na změnu, novost a vývoj. Souhlasím zde s Jiráskem, zejména v bodě otevřenosti vůči lidské tvořivosti.

49 Platón (1997, 803c-e).
} 
veškeré vzdělání a výchova jsou v samé podstatě zaměřeny na kultivaci duše. V tomto bodě je patrné Platónovo dualistické uvažování stavící do popředí duši nad tělo. Zdravé tělo nečiní automaticky zdravou i duši, avšak zdravá duše uvádí tělo do dobrého stavu. ${ }^{50} \mathrm{~V}$ posledku směřuje výchova, vzdělání i sportovní výkon u Platóna $\mathrm{k}$ dosažení areté, která je kvalitou duše a dostupná pro muže i ženy. ${ }^{11}$ Dle F. Novotného znamená termín areté u Platóna dobrou výkonnost, dobrý stav. Týká se nejen člověka, ale i např́klad zvířete, rostliny či nástroje. ${ }^{52} \mathrm{~V}$ kontextu lidského směřování se $\mathrm{k}$ areté dospívá skrze komplexní trénink, není tedy vrozená. ${ }^{53}$ Reidová při interpretaci Platónovy Ústavy upozorňuje na spojení mezi areté a duší:
„V Ústavě je areté chápána jako správné uspořádání a har- monické fungování trojdílné duše; je to zdravý stav duše, podobně jako spravedlnost je zdravý stav obce... fyzický trénink pomáhá harmonizovat psyché, připravit ji pro těž- kosti filosofování a kultivovat morální sílu požadovanou od služebníků obce.“

Dodává k tomu, že areté je kvalitou činící člověka dobrým i štastným. ${ }^{54}$

Kromě dosahování areté nastiňuje v dialogu Ústava Platón význam sportování pro dosahování dalších ctností. V kontextu morální kultivace řadíme Platóna k prvním autorům, kteří popisují schéma tzv. kardinálních ctností (spravedlnost - dikaiosyné, moudrost - sofia, statečnost andreia, uměřenost - sófrosyné). ${ }^{55}$ Pisk při interpretaci Platóna k těmto ctnostem uvádí, že člověk je může získávat a rozvíjet právě ve sportu. Antický sport (v podobě řecké gymnastiké) neslouží pouze k pěstění těla, ale v platónské koncepci slouží právě ke kultivaci duše. Sportovec skrze odříkání a disciplínu kultivuje žádostivou složku duše a pěstuje ctnost uměřenosti. Ve vytrvání v náročném zápolení kultivuje vznětlivou

\footnotetext{
50 Dombrowski (1979, s. 30-31), Platón (1993, 403d).

51 Reid (2012b, s. 12-13).

52 Novotný (1998, s. 620-621).

53 Reid (2011, s. 6).

54 Reid (2007, s. 160-162).

55 Bejczy (2011, s. 1).
} 
složku duše a získává ctnost statečnosti (vizte platónští strážci v dialogu Ústava). Je také postaven před výzvu uvážení správné míry a činění vhodných rozhodnutí. Optimálním jednáním v tomto směru kultivuje rozumovou část duše a ctnost praktické moudrosti (fronésis), připravuje si ovšem i půdu pro rozvoj teoretické moudrosti. Správným rozvojem daných částí duše a rozvojem zmíněných ctností nastává v duši spravedlivý stav mezi jejími částmi. Sport svou povahou rovněž vybízí k pěstování spravedlnosti ve smyslu dodržování pravidel a celkové úcty ke hře (fair play)..$^{6}$

Platónova filosofie se ovšem týká především duševního života, kterému je sportovní střetávání podřazeno. Filosof Jan Patočka hovoří o pojmu péče o duši (epimeleia tés psychés), který převzal právě z Platóna. V životním pohybu je pro duši žádoucí dostávat se z polohy úpadku (rozptýlenosti, nejednoznačnosti, pohlcenosti tělem) do polohy vzmachu (sjednocení, přehlednosti, rovnováhy s tělem). Dủležitou úlohu v tomto procesu má řecká paideia (praktická výchova), která by měla kultivovat samopohyb duše, učinit jej zřejmým, sebe-vědomým a dovést duši k nahlédnutí. ${ }^{57}$ Patočka uvádí, že péčí o duši v její podstatě a jejím živlu je filosofie.$^{8} \mathrm{~V}$ procesu životního formování a př́ípravy na filosofický život plní u Platóna tělesná cvičení a sportovní zápolení roli morálně rozvojových aktivit, které nejsou hlavní náplní lidského pobytu, ale jeho důležitou součástí.

\subsection{Aristotelés - uměřené sportování jako součást výchovy občana}

Platónův žák Aristotelés se rovněž zabýval výchovou a vzděláváním. Sám se atletem patrně nikdy nestal, ve svých spisech však věnoval sportovním zápolením pozornost. Ideálem pro něho byl ctnostný a po všech stránkách dobrý člověk. ${ }^{59}$ Jednou ze vzdělávacích metod byl pro Aristotela kromě gramatiky, hudby a kreslení také atletický trénink (tělocvik), který měl

56 Pisk (2010, s. 6-8, 14).

57 Blecha (2015, s. 410-411).

58 Patočka (1999, s. 126).

59 Laertios (1995, 5:28-30). 
athénské občany kultivovat nejen po stránce fyzické, nýbrž i po stránce intelektuální. ${ }^{60}$ Aristotelés totiž věřil, že zdraví a správné fungování duše (ve smyslu psyché) je podmíněno zdravím a správným fungováním těla (sóma) ${ }^{61}$ Vyvážená a harmonická krása atletova těla je pak odrazem jeho ctnostné duše, která u Aristotela vystupuje jako oživující a hybný princip těla (hylemorfické pojetí).

Tělesnou výchovupovažovalAristotelészadůležitýprvekproformování řecké mládeže. Měla být dle něho veřejná, společná a uspořádaná zákonem, jako tomu bylo ve Spartě, avšak nikoli tak jednostranná a ryze účelová. ${ }^{62}$ Správně prováděný tělocvik stál $\mathrm{v}$ Aristotelově koncepci výchovy na počátku, protože výcvik těla měl předcházet výcviku mysli. Tento názor se objevuje v Politice:

„Ježto jest zřejmo, že se má vychovávati dřive zvyky než naukou a že tělo se má cvičiti dříve než rozumová schopnost, plyne z toho, že se děti mají věnovati napřed tělocviku a zápasnictví; nebot' onen utváríí určitý stav tělesný, toto uschopňuje k výkonům."“63

Pohybová cvičení byla určena pouze chlapcům a kultivovala zejména mužnost, mohla ovšem pěstovat i krásu. Tento názor lze objevit v Aristotelově Rétorice:
„Krása ujinocha záležív tom, že má tělo způsobilék námahám, a to jak k těm, jež vyžadují hbitosti, tak k těm, k nimž je třeba síly, a hledíme-li k požitku, že se nám názorem líbí. Proto jinoši pěstující pětiboj bývají nejkrásnější, poněvadž jsou schopni hbitosti a zároveň síly."64

Uměřené tělesné cvičení zohledňující možnosti daného jedince vnímal Aristotelés jako prŕnosné a pozitivní. Byl ovšem kritický k přehnané

\footnotetext{
60 Aristotelés (1998, 1337b, 20-30).

61 Mechikoff (2014, s. 57).

62 Aristotelés (1998, 1333a-1337a).

63 Tamtéž, 1338b, 4-8.

64 Aristotelés (2010, 1361b, 5-15).
} 
fyzické aktivitě, která ničila zdraví malých chlapců. Ostře odsuzoval tendence vychovávat z mládeže pouhé atlety, zejména $\mathrm{z}$ toho důvodu, že se tím „... škodí tvaru a vzrůstu tělesnému...“65. Byl si vědom neblahých důsledků, které s sebou nadměrná fyzická námaha přináší. To je možné vypozorovat mimo jiné na tomto jeho názoru objevujícím se v Politice:

„... nebot’ až do dospělosti jest třeba prováděti lehčí cviky a vyloučiti nepřirozené stravování a každou těžkou práci, aby se nepřekáželo vzrůstu; nebot’ významným důkazem pro to, jaké škody to působí, jest skutečnost, že v seznamu olympijských vítězů najdeme jen asi dvě nebo tři jména těch, kteří zvítězili jako muži i jako hoši, poněvadž nepřirozeným cvičením v mládí vyčerpali svou sílu..."66

Základním cílem pohybového zápolení bylo uschopnit člověka $k$ vyšším výkonům, spojeným primárně s jeho rozumovou činností. Skrze tělesné cvičení mohl člověk dosahovat dokonalosti (areté), kterou Aristotelés ve shodě s Platónem vnímal jako produkt opakované činnosti, nikoli jako vrozený stav ${ }^{67} \mathrm{~K}$ tomu, aby mohl jedinec této dokonalosti nabýt, je třeba, aby prošel náročným tréninkem a habituací a správné chování měl jako zvyk (ethos). Tělesné cvičení za účelem pěstování správných zvyků má být dle Aristotela středem mezi extrémy nedostatku a přemíry, podobně jako v př́padě jeho koncepce ctností. ${ }^{68}$ Tento střed je ovšem pro každého odlišný, protože tělesné proporce i duševní schopnosti jedinců nejsou stejné. V Etice Níkomachově uvádí Aristotelés následující prř́klad:

„... nebơ jestliže pro někoho jest mnoho snísti za deset min ( 1 mina $=$ cca $0,57 \mathrm{~kg}$, pozn. autora), za dvě pak málo, nepředepíše cvičitel šest; nebot i toho snad bude mnoho nebo

\footnotetext{
65 Aristotelés $(1998,1338 b, 11)$. Tento Aristotelův postoj je třeba vidět v dobovém kontextu jako určitou reakci na vzestup profesionálního sportu.

66 Tamtéž, 1338b, 40-1339a, 5.

67 Reid (2011, s. 6-7).

68 V Etice Níkomachově (1996, 1106b, 24-30) Aristotelés uvádí konkrétně o mravní ctnosti následující: „Ctnost se týká citů a jednání, v nichž nadbytek jest chybou a nedostatek bývá kárán, střed však bývá chválen a jest správný; a toto oboje př́sluší ctnosti.“
} 
málo pro toho, kdo to má požíti; pro Mílóna (slavný řecký atlet, pozn. autora) totiž málo, pro začátečníka $\mathrm{v}$ atletice mnoho. Podobně i při běhu a zápolení.“69

K tomu, aby člověk správnou míru v jednání rozpoznal, potřebuje mít praktickou bystrost/moudrost (fronésis), jež je záležitostí praktického rozumu a dospívá se k ní skrze životní zkušenosti. ${ }^{70}$

Do značné míry se Aristotelés shoduje s Platónem a Sókratem, když u něho tělesné cvičení a sport figurují jako podstatný edukační prvek. $\mathrm{V}$ uměřené podobě přivádí člověka $\mathrm{k}$ hodnotám, o něž je třeba poctivě usilovat. Správně provozovaná fyzická aktivita pomáhá jedinci stát se dobrým a krásným, tedy k harmonickému ideálu kalokagathia. Kritický byl Aristotelés k profesionalizaci sportovního závodění, které nabývalo ve 4 . stol. př. n. l. značné popularity. ${ }^{71}$ Naopak vyzdvihoval důležitost rozvíjení duševních stránek jednotlivce, především činnost vědeckou a rovněž veřejnou. Životní naplnění a blaženost (eudaimonia) nespatřoval v lovu, hraní či sportovním závodění, ale v činnosti duševní (zejm. rozjímání, identifikaci a pěstování ctností), která odpovídá rozumové podstatě (esenci) člověka. ${ }^{72}$

\section{Antické Řecko, dobrý sport a dobrý život}

Uvažování o antickém řeckém sportu a hodnotách v něm přítomných představuje pro dnešního badatele výzvu v podobě co nejpřesnějšího nahlížení na to, jaká byla tehdejší skutečnost. Jirásek s odkazem na Machovce trefně naznačuje, že antické řecké ideály a hodnoty přítomné ve sportovním zápolení je potřeba především prožívat v současnosti. ${ }^{73}$ V praktickém uvažování tak nejde o to, jaký byl řecký sport a atlet (byt

69 Tamtéž, 1106a, 35-1106b, 5 .

70 Reid (2011, s. 73).

71 Specializovaní atleti se v antickém Řecku objevují již dříve. Ve století 4. počet profesionálních atletů ovšem významně stoupl. Profesionální atleti, specializující se již na konkrétní disciplíny, tak byli skrze tělesné cvičení, bohatou stravu a hojný spánek vedeni k maximalizaci svých fyzických možností. Takto pojatá profesionální atletika se stala terčem ostré kritiky, mimo jiné i z řad filosofü. (Olivová, 1988, s. 139-144).

72 Tamtéž, s. 137.

73 Jirásek (2005, s. 213). 
i toto může být relevantní), ale především o to, jaké hodnoty a aspekty sportování př́tomné $\mathrm{v}$ antickém Řecku rezonují s lidskou bytostí natolik, že stojí za to je žít i v současnosti. Hodnoty a ideály (př.: areté, kalokagathia, isonomia, andreia či aristeia ${ }^{74}$ ) provázané s antickým řeckým sportem odrážejí touhu člověka být ve světě autentickým, ryzím, a pravdivým způsobem. Otázka provozování sportu se zde prolíná s otázkou vedení dobrého života. V kontextu období antického Řecka a klasických myslitelů Sókrata, Platóna a Aristotela se proto táži, jaký sport je dobrý a jakou úlohu takovýto sport hraje v otázce vedení dobrého života. Obě otázky jsou vysoce relevantní pro současného člověka, který může sport více než $\mathrm{v}$ předchozích historických etapách vnímat jako globální fenomén.

\subsection{Dobrý sport}

Hovoříme-li o dobrém sportu, považuji za podstatné rozlišit, zda označení „dobrý" se týká spíše aktivity samotné (zde mám na mysli např. rovnou soutěž, dopředu nejistý výsledek, či morální hledisko - kdy např. nejde primárně o destrukci oponenta), či zda je do aktivity přináší sportovec samotný, tj. zda jsou otázkou sportovcova př́ístupu (zde podstatná rovina ctností), či zda se případně týká sportovního prostředí a jeho hodnot (zde je zásadní myšlenka, že sport je ovlivněn společností a kulturou, ve které je provozován, a rovněž na ně sám působí). Při uvažování o dobrém (a špatném) sportu máme na mysli právě tyto tř̌i složky. Dobrý sport pak zahrnuje dobrost každé z těchto tř́ složek, které se v praxi vzájemně ovlivňují. Při pohledu na antický řecký sport a myslitele klasického období vystupuje do popředí především složka nastavení a přístupu sportovce, což souvisí s rozvojem morálního uvažování o člověku v daném období. Reflexe aktivity a hodnotového prostředí jsou zde ovšem také přítomné a pokouším se na ně upozorňovat. Výrazem dobrý označuji to, co probíraní myslitelé za dobré považovali a pro co argumentovali.

V sókratovském duchu navrhuji za dobrý sport označit ten, který provozujeme ctnostně a který nám umožňuje rozvoj a používání rozumové kapacity. Nejednalo by se tedy o sport, který nás degraduje jako rozu-

74 Hrdinství. 
mové bytosti (např. forma drsných zápasů75, extrémní používání naší tělesné složky vedoucí k její degradaci i degradaci rozumu), ani o sport s cílem vyhrát za každou cenu (bez respektu k soupeři a pravidlům). Reidová si zde všímá souvislosti mezi filosofickým tázáním a sportovním zápolením. Dle ní Sókratés navštěvoval athénská gymnasia za účelem získání mladých atletů pro filosofii, zejména pro jejich předpokládaný zájem o kultivaci ctností. Na rovině filosofické debaty se snažil účastníkům nastavit zrcadlo jejich myšlení a pomáhat jim v dosahování vědění (epistémé). V podobném duchu interpretuje Reidová ideální sportovní zápolení jakožto kooperativní soutěž (cooperative competition), kdy atleti spolu nesoupeří za účelem poražení či ponížení oponenta, ale ve vzájemném férovém střetu se vzájemně respektují, vydáváním svého maxima si pomáhají poznávat sebe sama, rozvíjet své schopnosti, a vytvářejí prostředí pro vzájemné získávání a rozvoj ctností. ${ }^{76}$ Reidová spatřuje pojítko mezi sókratovským dialogem a sportovním zápolením v tom, že obě disciplíny se zaměřují na hledání pravdy. Atletické soutěže dle ní vykazují znaky autentického dotazování77 a nestranného testování, podobně jako je tomu u Sókratova filosofického dialogu. Takovýto „sókratovský“ sport je procesem odkrývání pravdy o sobě, a to skrze tělesné zápolení a kooperaci s druhými.

V platónském duchu se jako dobrý sport jeví ten, který kultivuje jednotlivé složky naší duše, vede k rozvoji a předvádění ctností, který v kráse a harmonii lidského pohybu ukazuje na kvalitu duše a který uschopňuje člověka k prospěšnému fungování ve společnosti. Podrobněji hovoří o dobrém sportu u Platóna J. Pisk. Dle něho souvisí úroveň sportu se složkou duše, kterou primárně angažuje. Sport na žádostivé rovině duše je založen na získávání materiálních statků v podobě cen na soutěžích. Sport na vznětlivé (emocionální) rovině duše je založen na elementárním agónu, který se snaží dojít naplnění ziskem cti a slávy. Jako nejlepší označuje Pisk sport pojící se s rozumovou složkou duše,

75 Na možnou námitku, že rozvoj rozumnosti není jediným úkolem dobrého lidského života, by bylo možné reagovat v aristotelském duchu tak, že rozumnost a používání rozumu jsou natolik charakteristické pro člověka, že pokud tuto složku aktivně degraduje, žije poté jiný život než přirozeně lidský.

76 Reid (2011, 43-53).

77 Reid (2009, s. 40, 45). 
u kterého je primární nikoli zápasení se soupeři, ale dokonalé provádění pohybů, při kterém se dosahuje dokonalé spolupráce těla s rozumem. $\mathrm{Na}$ této úrovni sportovec soupeří sám se sebou, překračuje vlastní (původní) limity a naplňuje sám sebe. Dle Piska pouze takovýto sport může člověku jakožto myslící bytosti přinášet uspokojení, protože přesahuje fyzický svět a dotýká se věčného a neměnného světa idejí. ${ }^{78}$ Pisk správně podotýká, že je obtížné najít sport, který by spadal pouze do jedné z kategorií. Na praktické rovině se motivy sportovce a jeho př́istupy prolínají. Spíše než o usilování o nejvyšší kategorii se jako reálné jeví harmonizace motivů (jednotlivých složek duše) a jejich rozumný poměr, který ovšem znamená, že atlet si je vědom přesahu sportovního zápolení a aktivně ho pěstuje. Dobrý sport tak angažuje celého člověka, přivádí ho do kontaktu se sebou samým a umožňuje mu rovněž skrze časovost a tělesnost kontakt s dimenzemi reality, které se jinak obtížně odkrývají. Považuji za žádoucí doplnit, že pěstování takovéhoto sportu se pro skutečné uvědomění jeho významu pojí s filosofickou reflexí samotného sportovcova výkonu.

$\mathrm{V}$ aristotelské koncepci můžeme za dobrý sport označit především ten, který není provozovaný $\mathrm{v}$ přehnané míre, ale který kultivuje tělo a plní roli prostředku pro př́pravu na veřejný, resp. kontemplativní život. Dle Reidové je Aristotelův ideální atlet v pravé podstatě kalos kagathos, krásný a v morálním smyslu dobrý/řádný člověk, který se do svého současného bytí zformoval usilovným tréninkem a konáním krásných a společensky prospěšných skutků. Takovýto občan je schopný rozeznávat, co je dobré a krásné, a aktivně $\mathrm{k}$ daným věcem tíhnout a jednat v souladu s nimi. ${ }^{79}$ Dobrý sport v Aristotelově podání by tedy znamenal především takovou činnost, která je provozována v rozumné míře, čímž přispívá, podobně jako u Platóna, k rozvoji tělesné krásy a ke kultivaci a demonstraci ctností.

Na obecné rovině se dobrému sportu s ohledem na období antiky věnují z hermeneutického a fenomenologického hlediska Jirásek, Oborný a Hurych, kteří hovoří o autentickém a neautentickém sportu. Druhé zmíněné označují pojmem techné athlétiké, což představuje úsilí

78 Pisk (2006).

79 Reid (2020, s. 65-72). 
o rozvoj některých částí lidského těla, aniž by byl zohledněn člověk v holistické perspektivě. ${ }^{80}$ Ve Slovníku antické kultury je termínem techné athlétiké označen úpadkový stav řecké gymnastiky pěstované profesionálními atlety jakožto zápasnické řemeslo. Negativita vyplývá z údajného primadonství, korupce, rozněcování nízkých pudů, soutěžení v hrubé síle a pěstění jen těch částí těla, které jsou potřebné pro dosažení vítězství či získání rekordu, což vedlo k tělesné deformaci. ${ }^{81}$ Proti tomu kladou zmínění autoři koncept techné gymnastiké stavící do popředí přirozenou lidskou sílu, harmonický rozvoj osobnosti (vizte platónský sport), autentický prožitek charakterizovaný hlubokým vnímáním časovosti a rovněž krásu lidského pohybu. Autoři upozorňují na obtížnost určení hranic mezi autentickým a neautentickým sportem, protože oba koncepty se mohou v praxi v různých ohledech mísit a splývat. Proto je potřebná citlivost náhledu a pečlivé rozlišování, které mohou odkrývat, o jaký typ sportu se jedná. V souvislosti s autentickým modem sportu zmiňují atributy jako subjektivitu (osobní angažovanost pro výkon), kreativitu a hravost. ${ }^{82}$

\subsection{Role sportu v kontextu dobrého života}

Po identifikaci možných pohledů na dobrý sport se nabízí otázka, jakou úlohu může sport (konkrétně výše identifikovaný dobrý sport) ve společnosti a obecněji v kontextu dobrého života plnit. Již u Xenofana ${ }^{83}$ se objevuje myšlenka, že sportovní výkon a fyzickou zdatnost nemůžeme nadřazovat moudrosti a že z rychlosti nohou či atletovy excelence se obec nestává lepší. Xenofanés poukazuje na relativně nízkou hodnotu sportovních zápolení pro formování obce a ukazuje, že spíše než o fyzickou zdatnost jde v lidském životě o duševní kultivaci ${ }^{84}$ Myslitelé Sókratés, Platón a Aristotelés nabízejí diferencovanější pohled, když ve sportu spatřují výchovný a vzdělávací potenciál. Dobrý sport $\mathrm{v}$ jejich podání formuje řádného občana a plní důležitou roli při jeho osobnostním i so-

80 Jirásek, Oborný \& Hurych (2018, s. 5).

81 Bahník et al. (1974, s. 85).

82 Jirásek, Oborný \& Hurych (2018, s. 5-9).

83 Xenofanés, Zlomky DK 21 B 2.

84 V moderním pojetí se s podobnou kritikou sportu lze setkat např. u N. Chomskyho. 
ciálním růstu. Shodují se ovšem v tom, že vedení dobrého života spočívá v něčem jiném než v pouhém provozování sportovních aktivit. Samotná problematika vedení dobrého života je značně komplexní. V následujících řádcích se proto pokusím nastínit roli dobrého sportu (resp. sportu popsaného výše uvedenými žádoucími vlastnostmi) v kontextu dobrého života u tradičního představitele eudaimonistického pojetí etiky a filosofické antropologie, již diskutovaného Aristotela. Jeho náhled na dobrý život se navíc v mnohém (byt ne ve všem) shoduje s pohledy Sókrata a Platóna.

Pro Aristotela je nejvyšším cílem lidského života dosažení blaženosti (eudaimonia). Tímto pojmem se zabývá především v první a desáté knize své Etiky Níkomachovy. Blaženost chápe jako nejvyšší dobro a blaženého člověka charakterizuje jako toho, kdo dobře žije, dobře jedná a dobře se má. ${ }^{85}$ Pro výměr toho, co činí člověka blaženým, je možné odkázat na Aristotelovu koncepci rozdělení způsobů života a druhů dobra. Dle Aristotela jsou tři způsoby života, které nazývá jako nejvíce vynikající. Jedná se o život poživačný, politický a rozjímavý, který je řazen nejvýše. ${ }^{86}$ Dobra pak Aristotelés dělí na zevnější, tělesná a duševní, přičemž duševní dobra chápe jako nejvíce vhodná $\mathrm{k}$ vyhledávání. ${ }^{87}$ Blaženým v tom nejvyšším slova smyslu se dle Aristotela stává dospělý člověk (nikoli zvíře či malé dítě), který je kultivovaný ctností, vede rozjímavý (tedy filosofický) život podle rozumu a usiluje o duševní dobra ${ }^{88} \mathrm{~K}$ tomu však dodává následující:

„Zároveň jest zjevno, že potřebuje také zevnějších dober, jak jsme řekli; jest totiž nemožno nebo nesnadno, aby jednal krásně ten, kdo nemá nutných prostředků. Vždyt’ mnoho věcí se koná s pomocí přátel, bohatství a politické moci jako s pomocí nástroje; nedostatek některých dober docela kalí štěstí, např́klad nedostatek urozenosti, plodnosti a krásy; nebot' není zcela blažen ten, kdo jest ohyzdný, nízkého půvo-

\footnotetext{
85 Aristotelés (1996, 1095a, 15-20).

86 Tamtéž, 1095b, 15-20.

87 Tamtéž, 1098b, 10-16.

88 Tamtéž, 1100a, 1178a, 5-10.
} 
du, osamělý nebo bezdětný, a ještě snad méně, má-li někdo nezdárné děti nebo špatné práátele, anebo, ač byli dobří, zemřeli." ${ }^{\circ 9}$

Z uvedeného výčtu je patrné, že Aristotelés si uvědomuje, že pro dosažení dobrého života je zapotřebí i jiných než duševních dober, a přisuzuje určitý význam tělesné kráse a pohybové kultivovanosti.

Aristotelés se podrobně zabýval fenoménem volného času, který u něho tvořil protipól k zaměstnání. Jak uvádí Olivová, „pro něho byl celý lidský život rozdělen na zaměstnání (ascholiá) a volný čas (scholé)“. ${ }^{90}$ Právě ve volném čase měl jedinec získávat vzdělání a rozvíjet zejména své duševní stránky. $\mathrm{V}$ této souvislosti kladl Aristotelés, podobně jako Platón, důraz na hudbu, která byla protikladem $\mathrm{k}$ tělocviku, jenž kultivoval primárně tělo. ${ }^{91}$ Odmítal vyplnit volný čas hrou (patrně tedy i sportem), protože by se poté mohla stát účelem a cílem života:
„Bylo by to zajisté něco zvláštního, aby cílem byla hra a aby- chom se po celý život namáhali a zlé snášeli pro pouhé hraní... Bylo by věru pošetilé a př́liš dětinské starati se a pracovati jenom pro hru... Zdá se, že blažený život je život ctnostný; tento však jest životem vážné práce a nikoli hry.“92

Mnohem podstatnější pro dosažení blaženosti tedy pro něho byla činnost vědecká a činnost veřejná, kterými se člověk uvnitř společnosti realizoval. Namísto aktivit jako je lov, hra či atletické závodění tak byla u Aristotela jako náplň volného času vyzdvihována činnost duševní, spojená $\mathrm{s}$ rozvojem sebe sama a se službou společnosti. ${ }^{93} \mathrm{Je}$ ovšem potřeba dodat, že pohybové aktivity chápal jako podstatný prvek na cestě k blaženému životu, což je patrné na následujícím jeho výroku z Etiky Níkomachovy:

\footnotetext{
89 Tamtéž, 1099a, 32 - 1099b, 6.

90 Olivová (1988, s. 137).

91 Aristotelés (1998, 1338ab).

92 Aristotelés (1996, 1176b, 25 - 1177a, 5).

93 Aristotelés (1998, 1337a, 30 - 1338a, 10).
} 
„Blažený člověk však jako člověk bude potřebovati také zevnější pohody, nebot' jeho přirozenost se nespokojí rozjímáním, nýbrž vyžaduje, aby také tělo bylo zdravé a aby se mu dostalo potravy a ostatní péče.“94

V Aristotelově podání je dobrý život chápán komplexně jako složenina vícera činností a ačkoli je zacílen primárně na činnost vědeckou a rozumovou/kontemplativní (které přinášejí nejvyšší úroveň blaženosti a dobra), nelze si ho $\mathrm{v}$ jeho plnosti představit bez dosahování dober ostatních, mezi která patří dobrý tělesný stav či tělesná krása. $Z$ tohoto důvodu můžeme správně prováděné sportovní aktivity označit za nikoli hlavní, ale podstatnou součást dobrého života. Nutno ovšem dodat, že Aristotelés neposkytuje podrobněji rozpracovaný pohled na to, jaký typ sportu je dobrý9 95 a jakou konkrétní úlohu má sport v otázce vedení dobrého života hrát. Nabízí pouze obecný pohled na vhodnost intenzity a cílů, které má sportování (na rovině soutěží i tělesného cvičení) sledovat.

\section{Implikace do současného sportu}

Idealizování řeckého sportu by bylo selektivním pohledem na určité období a pěstované hodnoty. Jako celek působí sportovní zápolení Řeků rozmanitě, diverzitně i záhadně pro omezené množství dochovaných informací. Dochované záznamy a úvahy ovšem obsahují podstatné významy sportování pro rozvoj člověka i pro otázku vedení dobrého života, čímž jsou aktuální pro provozování sportu v dnešním světě. Je potřeba dodat, že problematika dobrého sportu a jeho role $\mathrm{v}$ otázce dobrého života není antickými filosofy rozpracována konkrétně. Současný badatel je tak vystaven před riziko činit zobecňující závěry, které postrádají informativnost pro praktický způsob života. Jako relevantní se mi proto jeví ptát se, jaké konkrétní implikace antické uvažování má pro současný sport, a to s ohledem na rozdíly v typu provozované aktivity (tj. konkrétní sport), kulturní zvyklosti, hodnoty a individualitu sportovce.

94 Aristotelés (1996, 1178b, 30 - 1179a, 5).

95 V Rétorice je ovšem patrné, že oceňuje pětiboj (pentathlon). 
Zde se pokouším načrtnout možné obecné směry uvažování o významu antické pohybové kultury pro současný sport (myšleno 21. století).

- Důraz na rozumnou intenzitu a optimální množství sportovních aktivit v životě sportovce je obzvláště relevantní v mládežnickém výkonově pojatém sportu, kde hrozí riziko vykořistování dětí př́lišným důrazem na striktní režim..$^{96}$

- Sport není pouze o vítězstvíi ${ }^{97}$ či pěstění tělesné složky, ale také nám pomáhá $\mathrm{v}$ rozvoji charakteru, tedy k získávání a kultivaci ctností.

- Dodržování pravidel a vyhýbání se jejich porušování (např. v podobě neužívání dopingu) je vymahatelné nikoli pouze na základě formální správnosti, ale protože takové jednání vede atleta k rozvoji jeho přirozené krásy a vnitřní „dobrosti“ (subjektivní perspektiva založená na etice ctností).

- Soupeř nemusí být vnímán jako nepřítel, kterého je potřeba za každou cenu porazit. Je naším př́itelem v soutěži (vizte D. Hyland a competition as friendship ${ }^{98}$ ), který nám ve vzájemném střetávání umožňuje poznávat vlastní schopnosti a činí nás lepšími (podobně jako my jeho).

Nabízí se otázka, nakolik jsou tyto a v textu dříve zmíněné myšlenky ohledně dobrého sportu realizovatelné v současném sportovním světě. Je podstata „dobrého sportu“ (ne)slučitelná s většinovými modely současného sportu? Je zřejmé, že ve výkonnostním, vrcholovém a profesionálním sportu je trendem důraz na maximální výkonnost, přibližování se na hranice vlastních možností a posouvání limitů. Perspektiva zdravého a rozumného přístupu ke sportování, která se odráží i ve výchovné a vzdělávací roli sportu u antických Řeků, je proto snadno vystavena před riziko vytlačení jednostranným důrazem na výsledek, produkci výkonu a maximalizaci tělesných kapacit. Pro implementaci antických

96 K etickým aspektům zdraví a dobrého života v mládežnickém sportu vizte Zurc (2019).

97 Edgar (2013, s. 131) uvádí, že sport jakožto soutěž (contest) v sobě obsahuje riziko být poražen.

I v individuálních sportech jako je horolezectví spatřuje jako důležitý prvek možnost selhání, které je pro sportovní zápolení zásadní a se kterým se sportovec vyrovnává.

98 Hyland (1978). 
řeckých ideálů do současnosti je potřeba si uvědomit, že sport, zejména ten mládežnický, není jednostrannou záležitostí, není pouhým prostředkem k realizaci ambicí, není cestou k materiálnímu zabezpečení, není pouhou prací, ale zahrnuje v sobě možnost rozvoje osobních kvalit (charakterových vlastností/ctností), sociálního a týmového cítění, ale i vztahu k přirozenému pohybu a vlastní tělesnosti. Takovýto sport zahrnuje i odevzdávání maxima a snahu vítězit, ovšem bere zřetel na zpo̊sob, jakým toho bude docíleno. Žít tuto perspektivu vyžaduje erudici, zápal a odvahu trenérů, sportovních funkcionářů, organizací, rodičů i samotných sportovců, kteří podobu sportu v dnešním světě utvářejí.

\section{Závěr}

Dějiny antického Řecka jsou prostoupeny tělesnými cvičeními a sportem, které v dějinném vývoji nabývaly rozmanitých podob a významů. Sportovní zápolení Řeků bylo podstatně provázáno s náboženstvím a filosofií. Sloužilo jakožto prostředek seberealizace, připodobnění božské sféře a sehrálo podstatnou úlohu i v oblasti výchovy a vzdělání. Sport tvořil důležitou součást života tehdejších Řeků a podílel se na formování zodpovědného a schopného občana polis. Reidová správně poznamenává, že atletika v kontextu antické výchovy nesloužila pouze jako fyzický trénink, ale byla cestou ke kultivaci silné duše schopné hledat a nalézat pravdu. Sportovní zápolení formovala občany tak, aby řádně dokázali sloužit své obci a vlasti. ${ }^{99}$ Svým přínosem si sport získal pozornost rovněž filosofů, kteří ho reflektovali, oceňovali, kritizovali a v některých případech i sami provozovali. V prríspěvku diskutovaní myslitelé Sókratés, Platón a Aristotelés si uvědomovali vzdělávací a výchovný (resp. etický) rozměr sportování a ve svých úvahách je rozpracovávali. ${ }^{100}$ Sport v jeho dobré podobě pro ně představoval vhodný způsob kultivace a tvořil nikoli hlavní, ale přesto do̊ležitou součást dobrého života. Takovýto sport přináší cenné inspirace pro dobu současnou, ve které tlak na výkon a uspokojivý výsledek mnohdy vytlačují formativní rozměr sportování.

99 Reid (2009, 45).

100 Etickému rozměru antického sportu s ohledem na (post)moderní důraz na estetický rozměr sportování se věnuje Zowislová, vizte Zowislo (2009, s. 91). 


\section{Literatura}

Arendt, H. (2009): Vita Activa. Přel. V. Němec. OIKOYMENH, Praha. Aristotelés (1996): Etika Níkomachova. Přel. A. Kř́ž. Rezek, Praha. Aristotelés (1998): Politika. Přel. A. Kříž. Rezek, Praha. Aristotelés (2010): Rétorika. Přel. A. Kř̌žz. Rezek, Praha.

Bahník, V. et al. (1974): Slovník antické kultury. Svoboda, Praha.

Bejczy, I. P. (2011): The Cardinal Virtues in the Middle Ages. Brill, Leiden, Boston.

Blecha, I. (2015): „Patočkova péče o duši mezi Sókratem, Platónem a Aristotelem." Filozofia 70 (6): 409-419.

Dombrowski, D. A. (1979): „Plato and Athletics.“ Journal of the Philosophy of Sport 6 (1): 29-38.

Edgar, A. (2013): „The Modernism of Sport.“ Sport, Ethics and Philosophy 7 (1): 121-139.

Guttmann, A. (2004): From Ritual to Record: The Nature of Modern Sport. Columbia University Press, New York.

Huizinga, J. (1971): Homo ludens: o původu kultury ve hře. Přel. J. Vácha. Mladá fronta, Praha.

Hyland, D. (1978): „Competition and Friendship.“ Journal of the Philosophy of Sport 5 (1): 27-37.

Jirásek, I. (2001): Prožitek a možné světy. Univerzita Palackého, Olomouc.

Jirásek, I. (2005): Filosofická kinantropologie: setkání filosofie, těla a pohybu. Univerzita Palackého, Olomouc.

Jirásek, I. (2009): „Nahota v kontextu pohybové kultury.“ Tělesná kultura 32 (2): 7-19.

Jirásek, I., Oborný, J. \& Hurych, E. (2018): „The Authentic and Inauthentic Sport In the Hermeneutic and Phenomenological Perspectives." Acta Facultatis Educationis Physicae Universitatis Comenianae 58 (1): 1-11.

Kouřil, J. (2016a): „Athlétai a sportovní tituly antického světa.“ Tělesná kultura 39 (1): 15-26. 
Kouřil, J. (2016b): „Sportovní příprava a trénink v řecko-římské antice.“ Česká kinatropologie 20 (2): 7-28.

Kouřil, J. (2019): „,Olympism“ and Olympic Education in Greek Antiquity." Studia Sportiva 13 (1): 74-84.

Kretchmar, R. S. et al. (2017): History and Philosophy of Sport and Physical Activity. Human Kinetics Publishers, Champaign, Illinois.

Kyle, D. (1983): „Directions in Ancient Sport History.“ Journal of Sport History 10 (1): 7-34.

Laertios, D. (1995): Životy, názory a výroky proslulých filosofů. Přel.

A. Kolár. Nová tiskárna Pelhřimov, Pelhřimov.

Martínková, I. (2012): „Jak rozumět kalokagathii?“ Tělesná kultura 35 (1): 93-105.

Mechikoff, R. A. (2014): A History and Philosophy of Sport and Physical Education: From Ancient Civilization to the Modern World. McGraw-Hill, New York.

Novotný, F. (1998): „O překládání z filosofického jazyka Platónova.“ Filosofický časopis 46 (4): 619-629.

Olivová, V. (1988): Sport a hry ve starověkém světě. Artia, Praha.

Patočka, J. (1996): Péče o duši I. Připravili I. Chvatík \& P. Kouba. OIKOYMENH, Praha.

Patočka, J. (1999): Péče o duši II. Připravili I. Chvatík \& P. Kouba. OIKOYMENH, Praha.

Pisk, J. (2006): „What Is Good Sport: Plato's View.“ Acta Universitatis Palackianae Olomucensis. Gymnica 36 (2): 67-72.

Pisk, J. (2010): „The Role of Cardinal Virtues in Sport.“ In Hosta, M. (2010): Philosophical Reflections in Sport: A Collection of Essays. International Institute for Sustainable Development, Policy, and Diplomacy in Sport, Ljubljana.

Platón (1993): Ústava. Přel. R. Hošek. Svoboda, Praha.

Platón (1997): Zákony. Přel. F. Novotný. OIKOYMENH, Praha.

Prach, V. (2005): Ǩecko-český slovník. Vyšehrad, Praha.

Reid, H. L. (2007): „Sport and Moral Education in Plato's Republic.“ Journal of the Philosophy of Sport 34 (2): 160-175. 
Reid, H. L. (2009): „Sport, Philosophy, and the Quest for Knowledge.“ Journal of the Philosophy of Sport 36 (1): 40-49.

Reid, H. L. (2011): Athletics and Philosophy in the Ancient World: Contests of Virtue. Routledge (Taylor \& Francis Group), Abingdon.

Reid, H. L. (2012a): „Athletic Beauty in Classical Greece: A Philosophical View." Journal of the Philosophy of Sport 39 (2): 281-297.

Reid, H. L. (2012b): Introduction to the Philosophy of Sport. Rowman \& Littlefield Publishers, Inc., Plymouth.

Reid, H. L. (2020): „Athletic Virtue and Aesthetic Values in Aristotle's Ethics." Journal of the Philosophy of Sport 47 (1): 63-74.

Svoboda, K. (1962): Zlomky předsokratovských myslitelů. 2. vyd. Nakladatelství ČSAV, Praha.

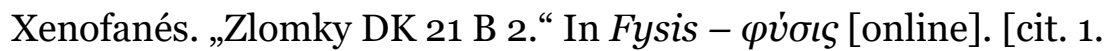
6. 2021]. Dostupné na: http://www.fysis.cz/presokratici/ xenofanes/bcz.htm.

Xenofón (1972): Vzpomínky na Sókrata. Přel. V. Bahník. Svoboda, Praha.

Zowislo, M. (2009): „On Virtue in the Context of Sport.“ Physical Culture and Sport. Studies and Research 47 (1): 89-94.

Zurc, J. (2019): „Ethical Aspects of Health and Wellbeing of Young Elite Athletes: Conceptual and Normative Issues." Synthesis Philosophica 68 (2): 341-358.

\section{Abstract}

Educational Role of Sport with Respect to the Thinkers Socrates, Plato, and Aristotle In Relation to the Problematics of a Good Sport and a Good Life

This manuscript deals with the problematics of ancient Greek sport, specifically with the significance of sporting practices and their educational role. Attention is given to a detailed analysis of the positions of the philosophers Socrates, Plato, and Aristotle. After demonstrating the context, the author presents and interprets fundamental philosophical and religious premises of the athletic performance and its educational role. Among the identified features are the effort of acquiring divine favour, immortality, higher social status, but also the ideals 


\section{Výchovná a vzdělávací role sportu u myslitelů Sókrata, Platóna a Aristotela ve vztahu k problematice dobrého sportu a vedení dobrého života}

of kalokagathia, areté, and other virtues. Important dimension of ancient Greek sport is also found in its formative potential which aims at the preparation for intellectual life. The main part of the article is focused on the approaches of the philosophers Socrates, Plato, and Aristotle towards the sporting practices. These thinkers made an important contribution to the understanding of the educational role of sport. Then, the author identifies a good sport according to these thinkers and examines the role of such sport in the context of a good life, which is considered in the Aristotelian perspective as achieving beatitude (eudaimonia). The aim of this article is to identify and highlight an educational purpose of sport, underlines its philosophical connotations, and demonstrate its possible role in the context of a good life.

Key words: philosophy of sport, philosophy of education, areté, kalokagathia, good sport, good life

Mareš, L. (2021): „Výchovná a vzdělávací role sportu u myslitelů Sókrata, Platóna a Aristotela ve vztahu k problematice dobrého sportu a vedení dobrého života.“ Filosofie dnes 13 (2): 44-72. Dostupné z www.filosofiednes.ff.uhk.cz. 